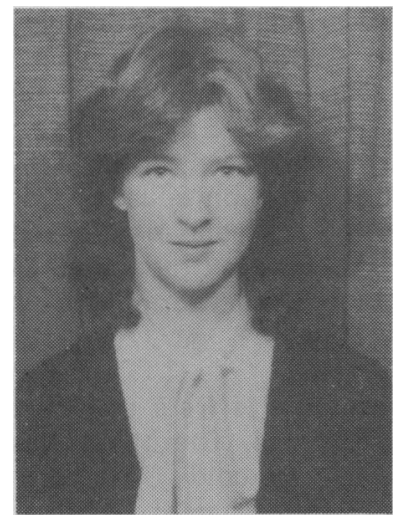

Elizabeth E. McKay

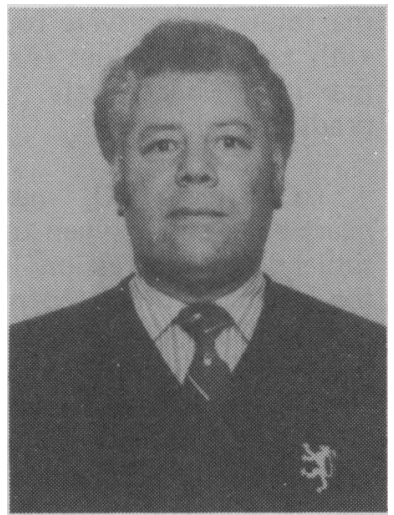

R. Braund

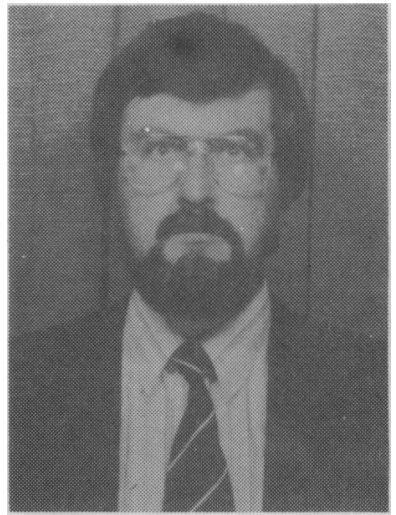

R. J. Chalmers

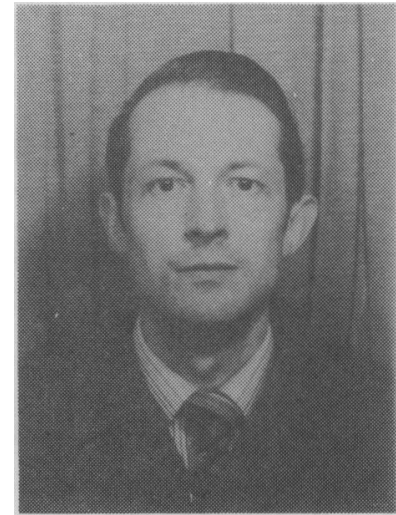

C. S. Williams

\title{
PHYSICAL WORK CAPACITY AND LUNG FUNCTION IN COMPETITIVE SWIMMERS
}

\author{
Elizabeth E. McKAY, BSc*, R. W. BRAUNDt, R. J. CHALMERS, PhD* and C. S. WILLIAMS, PhD* \\ *Department of Applied and Life Sciences, The Queen's College, Glasgow \\ tDirector of Swimming, Scottish Amateur Swimming Association
}

\begin{abstract}
Competitive swimmers require a high aerobic capacity to support the sustained performance of severe exercise. Maximal oxygen uptake values and blood lactate concentrations were measured in ten male and fifteen female swimmers from the Scottish National and Youth Squads 1981-82. Lung function tests were also performed to determine pulmonary efficiency. The results of these studies were compared with other investigations of international competitive swimmers and indicate a high level of fitness among Scottish national swimmers.
\end{abstract}

Key Words: Exercise, Swimmers, Oyxgen uptake, Pulmonary efficiency, Lactate.

\section{INTRODUCTION}

Competitive swimmers require a high aerobic capacity to support the sustained performance of severe exercise, and the measurement of the maximal rate of oxygen uptake which a swimmer can sustain during exercise provides a useful index of physical fitness. The maximum oxygen uptakes of swimmers have been determined under various conditions; running ( (̊strand and Saltin, 1961; Rowell et al, 1964), bicycling (Åstrand et al, 1963; Armstrong and Davies, 1981), using a biokinetic swim bench (Armstrong and Davies, 1981), during tethered and free swimming (Magel and Faulkner, 1967) and swimming in a flume (Holmér, 1974).

In an attempt to improve the training of Scottish National and Youth Swimming Squads it was decided to investigate parameters relating to aerobic capacity and lung function in swimmers. The present paper compares the results of preliminary studies in the Scottish swimmers with other published reports of physical performance in swimmers.

\section{METHODS}

The subjects, who were all members of the Scottish National or Youth Swimming Squad 1981-82, were divided into four groups according to age and sex. The groups comprised four males (mean age 17.5 years \pm 0.58 S.D.) and five females mean age 18.6 years \pm 1.34 S.D.) from the national squad, and six males (mean age 14.7 years \pm 0.52 S.D.) and ten females (mean age 14.1 years \pm 0.88 S.D.) from the youth squad. Height was measured without shoes and weight measured with the subjects in light swimming attire.

Pulmonary function tests were performed using a Vitalograph spirometer with a function analyser calibrated to measure volume in BTPS. The subjects used a mouthpiece and nose clips and were seated during these tests. Measurements of vital capacity (VC), forced vital capacity (FVC), forced expiratory volume measured over 1 sec $\left(F E V_{1}\right)$, and the percentage of FVC expired in $1 \sec \left(F E V_{\%}\right)$ were taken as the highest values of four trials. 


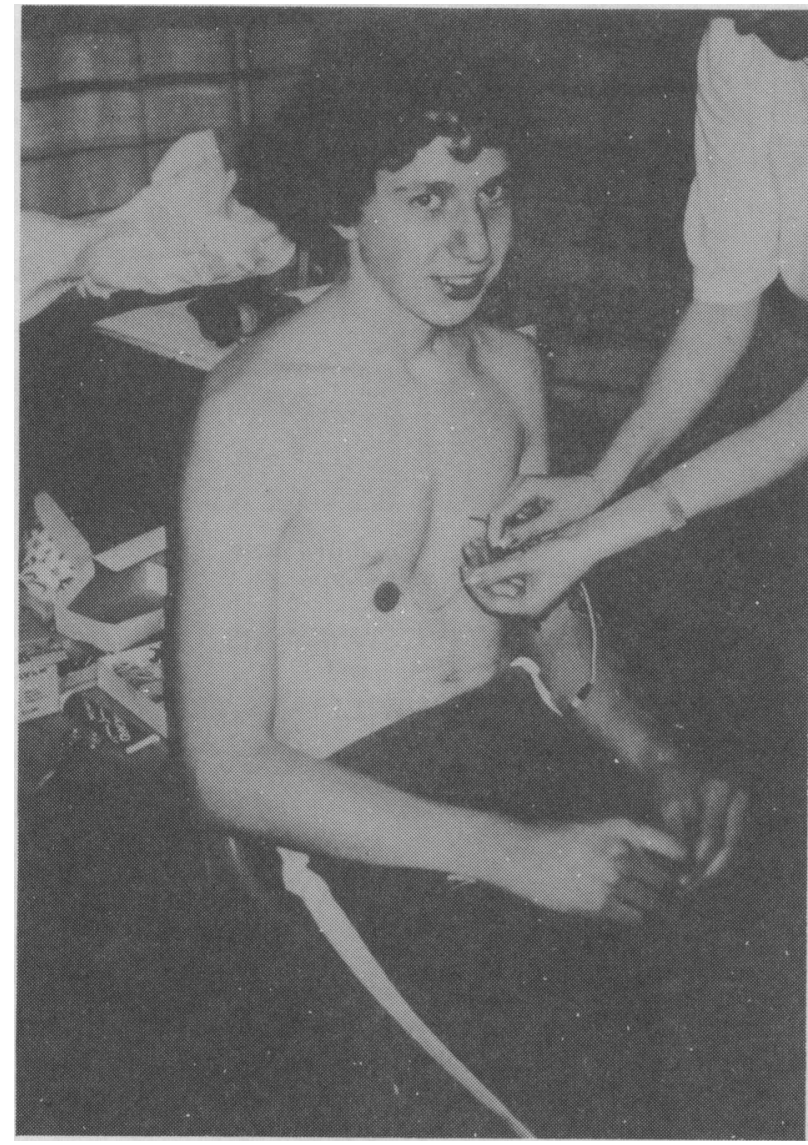

Fig. 1: A young swimmer being prepared for testing.

All the subjects performed a submaximal cycle ergometer test with incremental work load on a Kettler cycle ergometer with an Eddy-current breaking system. Saddle height was adjusted so that the subject's leg was almost extended when the cycle's pedal was at the lowest point in a revolution. The female subjects commenced cycling at a marked work load of $75 \mathrm{~W}$ and male subjects at 100W. Thereafter the load was increased by $25 \mathrm{~W}$ every five minutes, for fifteen minutes. Heart rate was recorded at rest and during the last fifteen seconds of each work load. Expired air was collected in Douglas bags and the oxygen and carbon dioxide concentrations determined using a paramagnetic $\mathrm{O}_{2}$ analyser (P. K. Morgan model OA500) and an infra red $\mathrm{CO}_{2}$ analyser ( $\mathrm{P}$. K. Morgan model 801d). The expired air was collected for five minutes at rest, two minutes at the lower work loads and one minute at the highest work load. Subjects were allowed to reach a steady state before gas collection commenced. The volume of expired air was continuously monitored using a flow transducer. Each subject was asked to give their maximum heart rate from previous experience. The reported maximum values were found to agree within a few beats with predicted values (Åstrand, 1960) and the subject's maximum heart rate was therefore taken as the predicted value.

To estimate $\mathrm{VO}_{2}$ max, the regression equation for heart rate and oxygen uptake was calculated for each subject. The regression line was then extrapolated to the subject's predicted maximum heart rate, giving an estimated value of $\mathrm{VO}_{2} \max$.

Finger-prick capillary blood samples were collected at rest and immediately after exercise. The blood was deproteinised immediately with ice-cold $0.6 \mathrm{~N}$ perchloric acid and centrifuged. The supernatant was then frozen until required for analysis of lactate concentration (Gutmann and Wahlefeld, 1974). On a separate occasion at the Scottish Amateur Swimming Association's National Short Course Championships, post-competition blood lactate concentrations were measured. Blood samples were obtained from the swimmers at the beginning of the session in which they would be swimming, and a subsequent sample collected four to five minutes after they had competed in the final(s) of their event(s).

Statistical analyses of the data was performed using Students t-test.

\section{RESULTS}

\section{Anthropometric measurements}

The mean age, height and weight for each group of swimmers are presented in Table I. The female swimmers of the youth squad were significantly smaller and lighter than the male swimmers of the youth and national squads, and the female swimmers of the national squad were smaller than their male counterparts. There were no significant differences in either height or weight between the various groups.

\section{Measurement of maximal oxygen uptake}

Mean values for estimated $\mathrm{VO}_{2} \max$ and $\mathrm{VO}_{2} \max$ per kilogram body weight are given in Table II. There was no significant difference in $\mathrm{VO}_{2} \max$ between the two groups of male swimmers but the female swimmers in the youth squad had a significantly lower $\mathrm{VO}_{2} \max$ than those in the national squad and both groups of male swimmers. When $\mathrm{VO}_{2}$ max was related to body weight, the only significant difference occurred between the male national squad and the female youth squad. The latter group having a lower $\mathrm{VO}_{2}$ max per kilogram body weight.

On completion of the exercise test, each group of swimmers had an elevated level of blood lactate (normal resting levels being in the range of 1.00-1.78 mM/l, Laudahn, 1959). There was no difference between the 


\section{TABLE I}

Physical characteristics of the Scottish swimming teams. (Means \pm S.D.)

\begin{tabular}{|c|c|c|c|c|}
\hline Team & $N$ & $\begin{array}{c}\text { Age } \\
\text { (years) }\end{array}$ & $\begin{array}{c}\text { Height } \\
\text { (cm) }\end{array}$ & $\begin{array}{c}\text { Weight } \\
(\mathrm{kg})\end{array}$ \\
\hline $\begin{array}{l}\text { 1a ơ swimmers } \\
\text { national squad }\end{array}$ & 4 & $\begin{array}{l}17.5 \\
\pm 0.6\end{array}$ & $\begin{array}{r}184.5 \\
\pm 3.7\end{array}$ & $\begin{array}{l}69.2 \\
\pm 3.3\end{array}$ \\
\hline $\begin{array}{l}\text { 1b ơ swimmers } \\
\text { youth squad }\end{array}$ & 6 & $\begin{array}{l}14.7 \\
\pm 0.5\end{array}$ & $\begin{array}{r}179.5 \\
\pm 7.8\end{array}$ & $\begin{array}{l}67.3 \\
\pm 7.8\end{array}$ \\
\hline Significance of & difference & $e-$ & NS & NS \\
\hline $\begin{array}{l}\text { 2a } 9 \text { swimmers } \\
\text { national squad }\end{array}$ & 5 & $\begin{array}{l}18.6 \\
\pm 1.3\end{array}$ & $\begin{array}{l}172.8 \\
\pm 5.9\end{array}$ & $\begin{array}{l}63.5 \\
\pm 8.5\end{array}$ \\
\hline $\begin{array}{l}\text { 2b } 9 \text { swimmers } \\
\text { youth squad }\end{array}$ & 10 & $\begin{array}{l}14.1 \\
\pm 0.9\end{array}$ & $\begin{array}{r}164.4 \\
\pm 8.2\end{array}$ & $\begin{array}{l}52.3 \\
\pm 9.2\end{array}$ \\
\hline Significance of & lifference & $e-$ & NS & NS \\
\hline Comparison of & roups: & $\begin{array}{l}1 a \text { and } 2 a \\
1 a \text { and } 2 b \\
1 b \text { and } 2 a \\
1 b \text { and } 2 b\end{array}$ & $\begin{array}{c}P<0.05 \\
P<0.001 \\
N S \\
P<0.001\end{array}$ & $\begin{array}{l}\text { NS } \\
P<0.001 \\
N S \\
P<0.001\end{array}$ \\
\hline
\end{tabular}

\section{TABLE II}

Estimated aerobic capacities of the Scottish swimming teams.

(Means \pm S.D.)

\begin{tabular}{|c|c|c|c|c|}
\hline & $\mathbf{N}$ & $\begin{array}{l}\text { Estimated } \\
\text { VO max } \\
(1 / \mathrm{min})\end{array}$ & $\begin{array}{l}\text { Estimated } \\
\mathrm{VO} \max / \mathrm{kg} \\
(\mathrm{ml} / \mathrm{min})\end{array}$ & $\begin{array}{l}\text { Post- } \\
\text { exercise } \\
\text { blood } \\
\text { lactate } \\
\text { conc. } \\
\text { (mM/I) }\end{array}$ \\
\hline \multirow{2}{*}{$\begin{array}{l}\text { 1a } \delta \text { swimmers } \\
\text { national squad }\end{array}$} & 4 & 4.72 & 68.57 & 4.17 \\
\hline & & \pm 0.79 & \pm 12.76 & \pm 1.57 \\
\hline \multirow{2}{*}{$\begin{array}{l}\text { 1b ơ swimmers } \\
\text { youth squad }\end{array}$} & 6 & 3.95 & 58.98 & 3.97 \\
\hline & & \pm 0.40 & \pm 5.36 & \pm 1.77 \\
\hline \multicolumn{2}{|c|}{ Significance of difference } & NS & NS & NS \\
\hline $\begin{array}{l}\text { 2a } \$ \text { swimmers } \\
\text { national squad }\end{array}$ & 5 & $\begin{array}{r}3.61 \\
\pm 0.77\end{array}$ & $\begin{array}{r}56.57 \\
\pm 8.32\end{array}$ & $\begin{array}{r}2.47 \\
\pm 0.35\end{array}$ \\
\hline $\begin{array}{l}\text { 2a } 9 \text { swimmers } \\
\text { youth squad }\end{array}$ & 10 & $\begin{array}{r}2.79 \\
\pm 0.47\end{array}$ & $\begin{array}{r}54.10 \\
\pm \quad 8.49\end{array}$ & $\begin{array}{r}4.50 \\
\pm 1.38\end{array}$ \\
\hline \multicolumn{3}{|c|}{ Significance of difference $P<0.05$} & NS & $P<0.05$ \\
\hline $\begin{array}{r}\text { Comparison of } \\
1 \mathrm{a} \\
1 \mathrm{a} \\
1 \mathrm{~b} \\
1 \mathrm{~b}\end{array}$ & $\begin{array}{l}\text { groups: } \\
\text { and } 2 a \\
\text { and } 2 b \\
\text { and } 2 a \\
\text { and } 2 b\end{array}$ & $\begin{array}{l}N S \\
P<0.001 \\
N S \\
P<0.001\end{array}$ & $\begin{array}{c}\text { NS } \\
P<0.05 \\
\text { NS } \\
\text { NS }\end{array}$ & $\begin{array}{l}\text { NS } \\
\text { NS } \\
\text { NS } \\
\text { NS }\end{array}$ \\
\hline
\end{tabular}

concentrations of lactate accumulated by the two groups of male swimmers but the female swimmers of the youth squad had significantly higher concentrations than the females of the national squad.

\section{Pulmonary function tests}

Table III gives the results of the pulmonary function tests performed on the swimmers. The mean values for VC and FVC were significantly greater in the male swimmers than in the females. The males of the national squad had a mean vital capacity of 6.11 litres which was $30 \%$ higher than the mean vital capacity predicted from Cournand's nomogram using height and age as indices. The females had a mean vital capacity of 4.63 litres which was $35 \%$ higher than that predicted from Cournand's nomogram in Documenta Geigy. Tables predicting the normal vital capacities of children, according to height, underestimate the vital capacities of the boys and girls in the youth squad by $32 \%$ and $18 \%$ respectively (Cotes, 1979). The mean FVC and $\mathrm{FEV}_{1}$ values of the swimmers were also greater than those predicted from tables and nomograms (Kamburoff and Brodie, 1971; Kamburoff and Woitowitz, 1973; Camprag, 1977). The FEV 1 in healthy male adults, depending on their age and size, is in the range of 1.25.7 litres (men) and 0.8-4.2 litres (women) (Cotes, 1979). The results for the male and female swimmers were at the higher end of these ranges.

The male swimmers recorded significantly larger $F_{1 E V}$ values than the females in the youth squad. The FEV \% in adults, depending on their age, is usually in the range $51 \%$ to $97 \%$ in males and $59 \%$ to $93 \%$ in females (Cotes, 1979). The FEV \% values were high in all the swimmers, although the male swimmers in the youth squad had a mean value which was significantly lower than those of the two groups of females.

\section{Post-competition blood lactate concentrations}

Post-competition blood lactate concentrations are presented in Figure 2. The male swimmers swam each event faster than the females and generally built up higher concentrations of blood lactate. Blood lactate concentration appeared to increase with distance up to 200 metres, at which point the highest levels of blood lactate were recorded.

Over longer distances, lactic acid concentrations were lower, except in the $\mathbf{4 0 0}$ metre individual medley event. There was some variation in lactate concentrations in different swimmers competing in the same event. For example, subject $Q$ finished the women's 200 metre freestyle with a higher blood lactate concentration than subjects $P$ and $O$, both of whom swam faster. There was also some variation in the lactate concentrations measured in the four competitors in the women's 100 metre breast stroke final. The lowest levels of lactate 


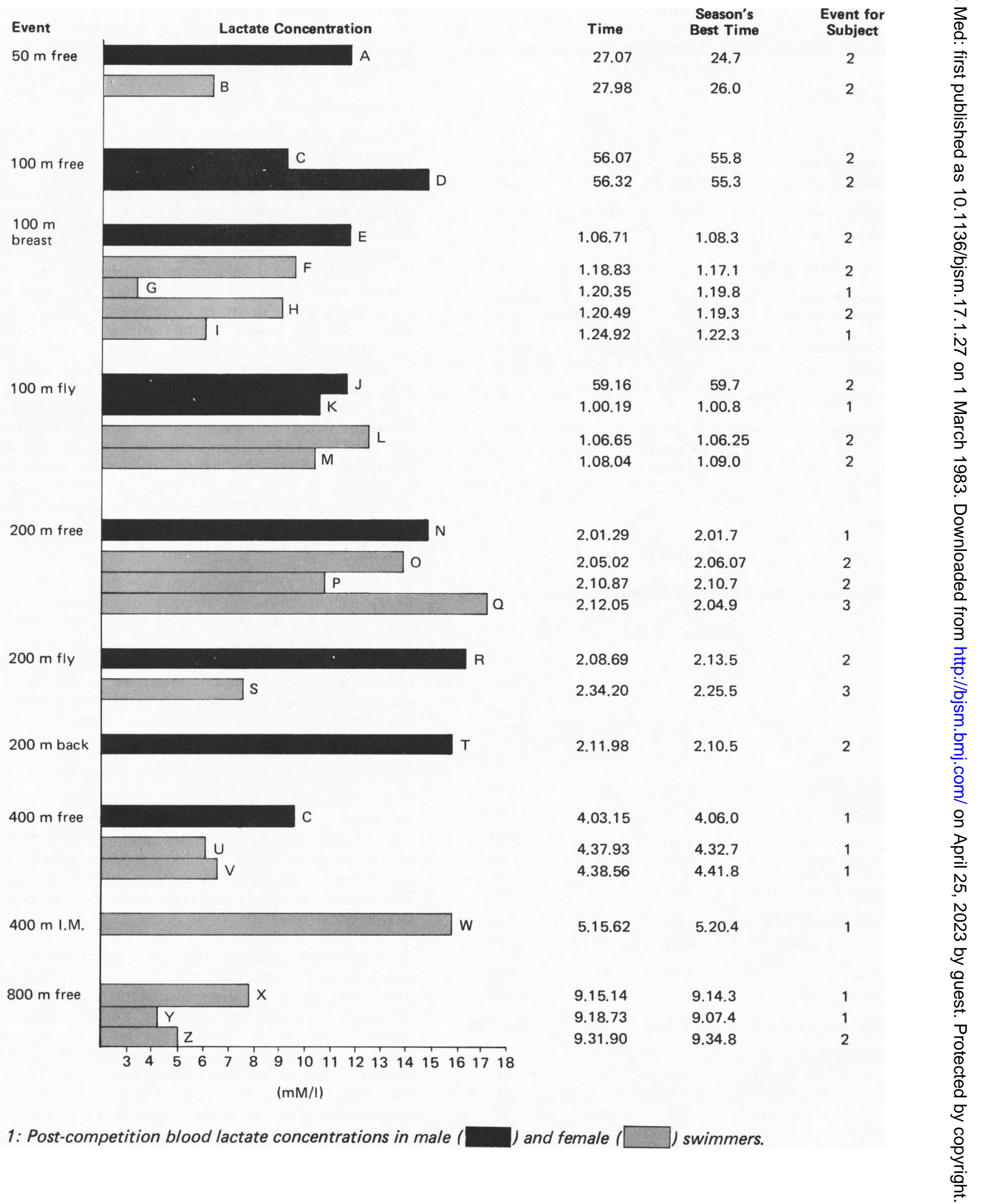


TABLE III

Results of pulmonary function tests (means \pm S.D.)

\begin{tabular}{|c|c|c|c|c|c|}
\hline Tean & $\mathbf{N}$ & $\begin{array}{l}\text { VC } \\
\text { (1) }\end{array}$ & $\begin{array}{c}\text { FVC } \\
\text { (1) }\end{array}$ & $\underset{(1)}{\mathrm{FEV}_{1}}$ & $\underset{(\%)}{\text { FEV\% }}$ \\
\hline $1 \mathrm{a}$ & $\begin{array}{l}\text { ठswimmers } \\
\text { national squad }\end{array}$ & $\begin{array}{r}6.11 \\
\pm 0.19\end{array}$ & $\begin{array}{r}6.10 \\
\pm 0.32\end{array}$ & $\begin{array}{r}5.62 \\
\pm 0.46\end{array}$ & $\begin{array}{l}93.4 \\
\pm 4.8\end{array}$ \\
\hline $1 b$ & $\begin{array}{l}\text { ठै swimmers } \\
\text { youth squad }\end{array}$ & $\begin{array}{r}5.88 \\
\pm 0.84\end{array}$ & $\begin{array}{r}5.96 \\
\pm 0.83\end{array}$ & $\begin{array}{r}4.76 \\
\pm 0.52\end{array}$ & $\begin{array}{l}83.9 \\
\pm 8.0\end{array}$ \\
\hline & Significance of difference & NS & NS & $P<0.05$ & NS \\
\hline $2 a$ & $\begin{array}{l}\text { \$ swimmers } \\
\text { national squad }\end{array}$ & $\begin{array}{r}4.63 \\
\pm 0.39\end{array}$ & $\begin{array}{r}4.66 \\
\pm 0.33\end{array}$ & $\begin{array}{r}4.31 \\
\pm 0.34\end{array}$ & $\begin{array}{l}95.2 \\
\pm 6.6\end{array}$ \\
\hline $2 b$ & $\begin{array}{l}\text { O swimmers } \\
\text { youth squad }\end{array}$ & $\begin{array}{r}4.25 \\
\pm 0.57\end{array}$ & $\begin{array}{r}4.26 \\
\pm 0.59\end{array}$ & $\begin{array}{r}3.91 \\
\pm 0.56\end{array}$ & $\begin{array}{l}95.4 \\
\pm 5.4\end{array}$ \\
\hline & Significance of difference & NS & NS & NS & NS \\
\hline & 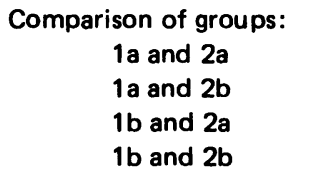 & $\begin{array}{l}P<0.001 \\
P<0.001 \\
P<0.05 \\
P<0.001\end{array}$ & $\begin{array}{l}P<0.001 \\
P<0.001 \\
P<0.05 \\
P<0.001\end{array}$ & $\begin{array}{c}P<0.001 \\
P<0.001 \\
N S \\
P<0.05\end{array}$ & $\begin{array}{c}\text { NS } \\
\text { NS } \\
P<0.05 \\
P<0.001\end{array}$ \\
\hline
\end{tabular}

recorded among the male swimmers were those of subject $C$ swimming in both the 100 metre and 400 metre freestyle events.

\section{DISCUSSION}

Maximal oxygen consumption is theoretically a good measure of cardio-respiratory performance, since it integrates the various processes concerned in the steadystate transfer of oxygen from the environment to active tissues. However, in practice, a maximal test is difficult to perform except on experienced laboratory subjects (Taylor, 1944; Durnin et al, 1960) so a submaximal test was used in the present study. Woynarowska (1980) and Binyildiz (1980) have both reported that $\mathrm{VO}_{2}$ max predicted from submaximal oxygen uptake values agrees closely with values obtained from maximal tests, when regression equations are calculated. In the present study a cycle ergometer was used because maximal oxygen uptake values for cycling are similar to those reported for swimming (Holmér, 1974).

Maximal aerobic capacity reaches its peak in both males and females between the ages of 18-20 years (Åstrand and Rodahl, 1977). The relative aerobic capacities of the male and female members of the Scottish National Squad, expressed as $\mathrm{VO}_{2}$ max per kilogram body weight $(68.6 \mathrm{ml} / \mathrm{kg} . \mathrm{min}$ and $56.6 \mathrm{ml} / \mathrm{kg} . \mathrm{min}$ respectively), compared favourably with those of national swimmers tested on the bicycle ergometer by Saltin and Åstrand (1967) who measured mean aerobic capacities of $67 \mathrm{ml} / \mathrm{kg} . \mathrm{min}$ in male swimmers and
$57 \mathrm{ml} / \mathrm{kg} \cdot \mathrm{min}$ in female swimmers. Cunningham and Eynon (1973) reported that young male and female swimmers from Ontario (mean ages 14.9 years) had aerobic capacities of $3.37 \mathrm{I} / \mathrm{min}(56.6 \mathrm{ml} / \mathrm{kg} . \mathrm{min})$ and $2.19 \mathrm{l} / \mathrm{min}(40.5 \mathrm{ml} / \mathrm{kg} . \mathrm{min})$ respectively, which are slightly less than the estimated values of the Scottish Youth Squad. Åstrand et al (1963) studied thirty of the best Swedish girl swimmers and found that their average aerobic power was $54 \mathrm{ml} / \mathrm{kg} . \mathrm{min}$. In the present study, the girls in the Scottish Youth Squad had an average aerobic power of $54.1 \mathrm{ml} / \mathrm{kg}$.min. From these comparisons, we can conclude that the Scottish swimmers had aerobic capacities similar to other international competitive swimmers.

Good swimmers tend to be above average for lung capacity. Training during adolescence increases vital capacity and total lung capacity due to the development of a broad chest and long trunk and this increased vital capacity helps swimmers maintain their buoyancy (Shephard, 1978). The vital capacities recorded by the males of the national squad were similar to previously published data on highly trained college swimmers (Magel and Faulkner, 1967) but those recorded by the males of the Youth Squad were higher than those reported by Vaccaro et al (1980) in well-trained swimmers (mean age 15.1 years), perhaps because the Scottish boys were taller and heavier. The mean vital capacities of the Scottish Youth Squad were also greater than the mean vital capacities of the boys and girls attending the 1961 Amateur Swimming Association's 
course, who recorded mean vital capacities of 5.4 litres and 4.2 litres, respectively (ASA, 1962).

The diaphragm and accessory muscles respond to physical training in the same way as other muscles, and it has been suggested that hypertrophy of the respiratory musculature may account for the higher values of FVC and FEV 1 (Stuart and Collings, 1959; Maksud et al, 1971), since these depend, in part, on the muscle power available. Vaccaro et al $(1980)$ found that the FVC and $F E V_{1}$ values of young male swimmers (13-16 years) were $10-16 \%$ above normal. The values of the Scottish swimmers ranged between 9-25\% above normal for FVC and between $19-25 \%$ above normal for $\mathrm{FEV}_{1}$. The $25 \%$ increase in FVC was measured in the male swimmers of the youth squad and may explain why their mean $\mathrm{FEV}_{\%}$ value was lower than the others, since $\mathrm{FEV}_{\%}$ decreases as FVC increases (assuming $\mathrm{FEV}_{1}$ remains constant). The mean $\mathrm{FEV}_{\%}$ of the other groups were above average which is contrary to the findings of Smalley, Newman and Thomson (1960) who recorded that the speed with which thirty good swimmers could take a breath was only about average (mean $\mathrm{FEV}_{\%}$ of $82 \%$ ).

The intense activity from large muscle masses and restricted patterns of breathing during competitive swimming favour the involvement of anaerobic energy release with the subsequent accumulation of lactate in the blood. According to Astrand's criterion, all the male and $\mathbf{5 0 \%}$ of the female swimmers were swimming anaerobically when competing. Differences in postcompetition blood lactate concentrations were observed in different swimmers competing in the same race. The explanation of this may be related to the number of prior events in which a swimmer had competed and whether or not there was sufficient time for the body to break down any accumulated lactic acid. Subject $C$ recorded the lowest levels of lactate among the male swimmers (Figure 1). Being an endurance swimmer he may have unconsciously remained around the limit of his aerobic power. An alternative explanation for his relatively low blood lactate concentration after the men's 100 metre freestyle event relates to the fact that he had previously swum in the $\mathbf{1 5 0 0}$ metre freestyle. Sawka et al (1979) recorded lower levels of lactate in swimmers who had previously swum in the 1000 yard freestyle event and suggested that this may be due to a reduction of muscle glycogen due to exhaustive exercise, although it is questionable whether the intensity and duration of this event would be adequate to significantly reduce muscle glycogen (Costill et al, 1971; Hermansen et al, 1967).

The results presented in this paper indicate a high level of fitness among Scottish national swimmers compared with other published reports. This may be a consequence of early training or endowment, but further study will be required to determine if improvement is possible in the various parameters measured.

\section{REFERENCES}

ASA, 1962 “Competitive swimming”. Educational Publications Ltd.

Armstrong, N. and Davies, B., 1981 "An ergometric analysis of age group swimmers". Brit.J.Sports Med. 15: 20-26.

Åstrand, I., 1960 "Aerobic work capacity in men and women with special reference to age". Acta Physiol.Scand. Suppl. 169.

Åstrand, P. O., Engström, I., Erkisson, B., Karlberg, P., Nylander, I., Saltin, B. and Thorén, C., 1963 “Girl swimmers with special reference to respiratory and circulatory adaptation and gynaecological and psychiatric aspects". Acta Paediat. Suppl. 147.

Åstrand, P. O. and Rodahl, K., 1977. Textbook of Work Physiology 2nd Ed. McGraw-Hill, New York.

Åstrand, P. O. and Saltin, B., 1961 "Maximal oxygen uptake and heart rate in various types of muscular activity". J.Appl.Physiol. 16: 977-981.

Binyildiz, P. O., 1980 "Prediction of maximal oxygen uptake in boys 11-13 years of age". Eur.J.Appl.Physiol. 43: 213-219.

Camprag, D., 1977. In: Lung Function Tables and Nomograms, Vitalograph Ltd., Buckingham.

Costill, D. L., Bowers, R., Branam, G. and Sparks, K., 1971 “Muscle glycogen utilisation during prolonged exercise on successive days". J.Appl.Physiol. 31: 834-838. 
Cotes, J. E., 1979. Lung Function, assessment and application in medicine, 4th Ed. Blackwell Scientific Publications, Oxford.

Cournand, A. Quoted by Rossier et al in Documenta Geigy, 6th Edition, 1968, p. 626. Geigy Pharm. Macclesfield. Cunningham, D. A. and Eynon, R. B., 1973 "The working capacity of young competitive swimmers, 10-16 years of age". Med.Sci.Spts 5: 227-231.

Durnin, J. V. G. A., Brockway, J. M. and Whitcher, M. W., 1960 "Effects of a short period of training of varying severity on some measurements of physical fitness". J.Appl.Physiol. 15: 161-165.

Gutmann, I. and Wahlefeld, A. W., 1974 " $L-(+)-$ lactate. Determination with lactate dehydrogenase and NAD". In: Methods of Enzymatic Analysis, 2nd ed. Ed: Bergmeyer, H. U. Verlag Chemie Weinheim and Academic Press Inc., New York and London.

Hermansen, L., Hultmann, E. and Saltin, B., 1967 "Muscle glycogen during prolonged exercise". Acta Physiol.Scand. 71: 129-139.

Holmér, I., 1974 "Physiology of swimming man". Acta Physiol.Scand.Suppl. 407.

Kamburoff, P. L. and Brodie, D. A., 1971 "Spirometric values in 540 healthy schoolboys". Br.J.Sports Med. 5: 205-211.

Kamburoff, P. L. and Woitowitz, H. J., 1973 “Nomograms of an industrial population”. Respiratory News Bulletin 17: 9-13.

Laudahn, G., 1959 "Fermentaktivitaten und konzentration von stoffwechselzwischenprodukten im blut bei leberund herzkrankheiten". Klin.Wschr. 37: 850.

Magel, J. R. and Faulkner, J. A., 1967 "Maximum oxygen uptakes of college swimmers". J.Appl.Physiol. 22: 929-938.

Maksud, M., Hamilton, L., Couths, K. and Wiley, R., 1971 "Pulmonary function movements of Olympic speed skaters from the US". Med.Sci.Sports 3: 66-71.

Rowell, L. B., Taylor, H. L. and Wang, Y., 1964 "Limitations to prediction of maximal oxygen intake". J.Appl.Physiol. 19: 919-927.

Saltin, B. and Åstrand, P. O., 1967 “Maximal oxygen uptake in athletes". J.Appl.Physiol. 23: 353-358.

Sawka, M. N., Knowlton, R. G. Miles, D. S. and Critz, J. B., 1979 "Post-competition blood lactate concentrations in collegiate swimmers". Eur.J.Appl.Physiol. 41: 93-99.

Shephard, R. J., 1978 "Human physiological work capacity". Cambridge University Press, Cambridge.

Smalley, B., Newman, F. and Thomson, M. L., 1960 "Changes in pulmonary diffusing capacity with exericse in athletics". Communication to Physiological Society.

Stuart, D. G. and Collings, W. D., 1959 “Comparison of vital capacity and maximum breathing capacity of athletes and non-athletes". J.Appl.Physiol. 14: 507-509.

Taylor, C., 1944 "Some properties of maximal and sub-maximal exercise with reference to physiological variation and the measurement of exercise tolerance". Amer.J.Physiol. 142: 200-212.

Vaccaro, P., Clarke, D. H. and Morris, A. F., 1980 "Physiological characteristics of young well-trained swimmers". Eur.J.Appl.Physiol. 44: 61-66.

Woynarowska, B., 1980 "The validity of indirect estimations of maximal oxygen uptake in children 11-12 years of age". Eur.J.Appl.Physiol. 43: 19-23. 